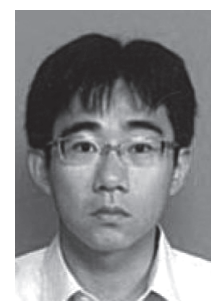

\title{
チューリッヒ工科大学に留学して
}

保田 尚俊*

\section{Study abroad in ETH Zurich}

by

\author{
Naotoshi YASUDA*
}

2016 年 4 月から半年間，アカデミックゲストとしてス イスのチューリッヒ工科大学 (ETH Zurich) に滞在して おりました，本稿では，そこで私が感じたことを述べさ せていただきたいと思います。

大学の研究室を訪問し, まず初めに驚いたことは, デ スクトップPCだけでなく, 付箋やホッチキス, シャープ ペンシルや消しゴムにいたるまで, 研究を行う際に必要 となる可能性のあるものすべてが用意されていたことで す。海外でそのような, 日本以上の細やかな気遣いをし て頂けるとは想像しておりませんでしたので, 非常に驚 いたことを覚えております。 また, 研究を行う際に必要 となるソフトウェアのセットアップが簡単にできた点に 関しても，驚きました，チューリッヒ工科大学では，ソ フトの使用に際して煩雑な手続きが無く, 初日に学内で 登録した自分のアカウント（この登録も5分ぐらいでで きました）のみで, 研究に必要なすべてのソフトを使用 することができました，日本では，ソフトウェアのライ センス認証の手続きや管理でいつも苦労しておりました ので, あまりの簡単さに感動いたしました.

研究室は国際色豊かで, 出身国も母国語も様々でした が, ドイツ語, 英語, イタリア語等の言語を使い分けな がら，議論が活発に行われておりました。お世話になっ た研究室では, 学生間の仲が良く, 皆親切で, 学内外の色々 な活動に一緒に参加させてもらうことができました，研 究室の学生の生活は, 日本に比べてメリハリがあるとい う印象でした. 研究室内は大学や外部機関から給料をも らいPh.D. studentとして研究をしている学生が多かった のですが, 彼らは契約で決められた時間はしっかり研究 し, それ以外の時間はスポーツ等の研究以外の活動をす るといった感じでした. 日本のPh.D. studentは学校に住 み着くぐらいに研究するというイメージが強いですが, スイスではライフワークバランスが重要視されておりま した.

研究の環境面に関しては, 初めての留学でいろいろと 心配をしておりましたが，うれしいことに，すべて杞憂 に終わりました. むしろ, 日本に比べ,ソフトウェアのセッ トアップ等の煩雑な作業に時間を割く必要がないため, 個人的には, 研究の環境は優れているのではないかと感 じました。
次に生活面に移りたいと思います。スイス滞在で一番 苦労したことは保険です. スイスでは, 長期滞在する場合, 保険の加入が義務付けられております。 スイスでは日本 のような国民皆保険制度はございませんので, 自分で保 険会社の保険を選び，加入しなければなりません，私は あらかじめ日本で海外留学用の保険に加入していったの ですが, 必死の抵抗にも関わらず, 結局その保険では補 償が不十分（けがの補償は無制限でなければならない） との理由で, 現地の保険にも加入しなければなりません でした．役所などの公的な機関を訪問すると英語が通じ るのであまり問題は生じないのですが，手紙で送られて くる公的な書類はすべてチューリッヒ市の公用語である ドイツ語で書かれております。 そのため, 保険の手続き に関しては非常に苦労いたしました，なお，スイスに留 学される際は日本で保険に加入していくのではなく，現 地（留学生向けの安い保険がございます）に到着後に加 入して頂くことを㘯针めいたします。

スイスの公用語はドイツ語, フランス語, イタリア語,

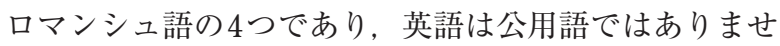
ん. しかしながら, 基本的には街中どこでも英語が通じ ます，そのため, 片言の英語しか話せず，ドイツ語やフ ランス語等は全くわからない私でも, 日常生活に支障を きたすような苦労をすることはほとんど有りませんでし た. また，チューリッヒ市内はトラム（路面電車のよう なもの）やバス等の公共交通網が発達しており, 人口密 度が高くなく，自然も豊かなため，日本にいるよりも快 適に生活ができました，ただし，スイスの物価は日本に 比べて，2倍程度と非常に高いので，お金に関しては苦労 することがあるかもしれません.

海外留学ということに対して, 留学前は様々な心配を しておりましたが, 実際はほとんど問題なく, 楽しく過 ごすことができました. さらに，日本では得ることので きない多くのものを得ることができました，若い学生の 皆様には是非とも海外留学をして頂き, 日本では得られ ない多くのことを学んで頂ければと思います。スイスは 英語圈ではないため, 日本から留学される方は少ないと 思いますが，日本人にとっては生活しやすく，また国際 色も豊かな国です．物価が高いことが難点ですが，個人 的には非常に留学をお勧めできる国です. 